\title{
CYTOTOXIC ACTIVITY OF PARTIALLY PURIFIED ESCHERICHIA COLI ALPHA HAEMOLYSIN
}

\author{
S. J. Cavalieri and I. S. SNyder* \\ Department of Microbiology, West Virginia University Medical Center, \\ Morgantown, $W V$ 26506, USA
}

\begin{abstract}
SUMmary. Alpha haemolysin, produced by Escherichia coli, grown in a chemically defined medium, was purified 19-fold and the endotoxin content reduced 2176 -fold by ultrafiltration and glycerol-gradient ultracentrifugation. Immunodiffusion of purified $\alpha$ haemolysin $(\mathrm{PH})$ against antiserum to crude haemolysin $(\mathrm{CH})$ revealed only one precipitation line. PH was cytotoxic in nanogram amounts for mouse-fibroblast $3 \mathrm{~T} 3$ cells, and the cytotoxicity exhibited proportional dose-response and time-course kinetics. The cytotoxic and haemolytic activities of $\mathrm{PH}$ were neutralised by immunoglobulins to $\mathrm{CH}$. A mutant, produced by treating the haemolytic wild type with mitomycin $C$, possessed all of the biochemical characteristics of the wild type with the exception that the extracellular products of the mutant were non-haemolytic and noncytotoxic.
\end{abstract}

\section{INTRODUCTION}

The ability of Escherichia coli to cause disease in man and in animals is well recognised. Probable virulence factors include enterotoxins, endotoxin, and attachment and adherence factors. Some strains of E. coli are also haemolytic (Smith and Linggood, 1971; Minshew et al., 1978 $a$ and $b$ ) and can disrupt renal lysosomes in vitro whereas non-haemolytic strains do not (DePauw, Gill and Fried, 1971). Injection of haemolytic E. coli into rats resulted in mitochondrial degeneration in the kidney cells, in the absence of intrarenal bacteria (Fry, Fried and Goven, 1975). Fried and Wong (1970) also produced pyelonephritis in normal rats by intravenous injection of haemolytic $E$. coli but not by similar injection of non-haemolytic E. coli. Chaturvedi et al. (1969) demonstrated that haemolytic culture filtrates from $E$. coli were cytotoxic for chick-embryo fibroblasts, but they were able to destroy haemolytic activity and retain cytotoxicity by heating at $56^{\circ} \mathrm{C}$ for $1 \mathrm{~h}$.

Smith (1963) described two separate haemolysins produced by E. coli. One, $\alpha$ haemolysin, was filterable whereas the other, $\beta$ haemolysin, was cell bound. Calcium was required for the activity of both haemolysins (Snyder and Koch, 1966).

Purification of $\alpha$ haemolysin from $E$. coli grown in meat-infusion media has been attempted by several workers. Zwadyk and Snyder (1971) reported a 20- 
to 30 -fold purification by precipitation with $20-25 \%$ ethanol and re-precipitation by $30 \%\left(\mathrm{NH}_{4}\right)_{2} \mathrm{SO}_{4}$, but dialysis resulted in loss of activity. Rennie and Arbuthnott (1974) achieved a $4 \times 10^{3}$-fold purification by a multi-step process including $50 \%\left(\mathrm{NH}_{4}\right)_{2} \mathrm{SO}_{4}$ precipitation, re-precipitation in acetate buffer at the isoelectric point and Sephadex-G200 chromatography. Williams (1979) did not confirm these results but obtained a 900 -fold purification by slightly different methods.

The molecular weight of $\alpha$ haemolysin has been estimated by several workers and ranges from as low as 120000 (Williams, 1979), to as high as 600000 (Rennie and Arbuthnott, 1974). These differences may reflect the existence of various forms of a multimeric molecule.

The absence of studies on the purification and cytotoxic activity of the haemolysin produced in a chemically-defined medium (CDM) prompted us to purify the haemolysin from $E$. coli grown in CDM (Snyder and Koch, 1966) and determine its cytotoxic potential for mouse-fibroblast $3 \mathrm{~T} 3$ cells.

\section{MATERIALS AND METHODS}

E. coli strain and cultural conditions. E. coli type $\mathrm{O} 55$ was a clinical isolate from a patient with a urinary-tract infection at West Virginia University Hospital (Morgantown, WV). Isolated haemolytic colonies were identified as $E$. coli by gram staining and biochemical tests (Edwards and Ewing, 1972). These included fermentation of glucose, lactose, maltose, mannitol, inositol, salicin and sucrose; decarboxylation of lysine, arginine and ornithine; production of indole, hydrogen sulphide, urease and acetylmethylcarbinol; motility and methyl-red test. The standard inoculum was prepared and cultured in CDM as previously described (Snyder and Koch, 1966).

Preparation of crude $\alpha$ haemolysin $(\mathrm{CH})$. Two 2-L flasks, each containing $500 \mathrm{ml}$ of sterile $\mathrm{CDM}$, were inoculated with $5 \mathrm{ml}$ each of a standard inoculum, and incubated at $35^{\circ} \mathrm{C}$ for $10 \mathrm{~h}$ with shaking. The cultures were centrifuged at $4{ }^{\circ} \mathrm{C}$, the supernate was sterilised by filtration and the filtrate concentrated to $25 \mathrm{ml}$ at $4^{\circ} \mathrm{C}$ by an ultrafiltration pressure-dialysis system (Amicon Corp., Lexington, MA) with a XM-300 membrane (exclusion limit mol. wt 300 000). The concentrated $\mathrm{CH}$ was sterilised by filtration.

Preparation of purified $\alpha$ haemolysin $(\mathrm{PH})$. Glycerol solutions $(5 \%$ and $30 \%$ ) were made up in a medium (MCDM) consisting of $\mathrm{MgSO}_{4},\left(\mathrm{NH}_{4}\right)_{2} \mathrm{SO}_{4}$ and $\mathrm{Na}_{3} \mathrm{C}_{6} \mathrm{H}_{5} \mathrm{O}_{7}$ in the same concentrations as in $\mathrm{CDM}$ and adjusted to $p \mathrm{H} 5 \cdot 4$. The gradients $(32 \mathrm{ml})$ were poured into $1 \times 3 \cdot 5$-inch centrifuge tubes and $5 \mathrm{ml}$ of $\mathrm{CH}$ were layered on top of each gradient.. The tubes were centrifuged at $4^{\circ} \mathrm{C}$ for $20-21 \mathrm{~h}$ at $89100 \mathrm{~g}$ in a SW27 rotor (Beckman Instruments, Inc., Palo Alto, Ca). One-ml fractions were collected by siphoning and assayed for haemolytic activity. Fractions containing high haemolytic activity were pooled, dialysed in MCDM and sterilised by filtration.

Assay for haemolytic activity. A preliminary titration was performed as previously described (Snyder and Koch, 1966), except that $50 \%$ haemolysis was the endpoint, as judged visually. A quantitative assay was done by the use of $0 \cdot 1-\mathrm{ml}$ increments of the highest dilution of haemolysin that caused at least $50 \%$ lysis in the preliminary test. The volume was adjusted to 1 $\mathrm{ml}$ with calcium saline (Snyder and Koch, 1966) and $1 \mathrm{ml}$ of a $1 \%$ suspension of thrice-washed sheep red-blood cells (SRBC) in saline was added. After $1 \mathrm{~h}$ at $37^{\circ} \mathrm{C}$ the unlysed cells were removed by centrifugation and the supernate decanted into a tube containing $1.5 \mathrm{ml}$ of saline. The optical density at $545 \mathrm{~nm}$ was converted to percentage lysis by reference to a standard curve. The final titre was calculated by dividing the titre in the preliminary assay by the volume of the dilution that gave $50 \%$ lysis in the quantitative assay (HU50).

Chemical analyses. Protein concentrations were measured by the microassay method (Bradford, 1976) with bovine-serum albumin (Sigma Chemical Co., St Louis, MO) as a standard. 
Endotoxin concentrations were measured by the limulus-lysate technique (Ward and Hill, 1972). E. coli O26:B6 lipopolysaccharide (Difco Laboratories, Detroit, MI) was used as the standard.

Carbohydrate was measured by the phenol-sulphuric acid method of Dubois et al. (1956), heptoses by the method of Osborn (1963) and 2-Keto-3-deoxyoctonate (KDO) by the method of Waravdekar and Saslaw (1959).

Lipids were detected by thin-layer chromatography (TLC) as described by Kates (1972). The sample was extracted with chloroform: methanol $(2: 1 \mathrm{v} / \mathrm{v})$. The chloroform layer was removed, evaporated to dryness in nitrogen and redissolved in diethyl ether. The extract was spotted on a $5 \times 20$-cm strip of chromatography medium (ITLC type, Gelman Instrument Co., Ann Arbor, MI). Ascending TLC was run in petroleum ether:diethyl ether:acetic acid $(50: 10: 1)$ and chloroform:methanol:acetic acid:water $(85: 15: 10: 4)$ solvent systems to detect individual lipids and total lipids respectively. After drying, the strips were sprayed with $50 \% \mathrm{H}_{2} \mathrm{SO}_{4}$, heated at $230^{\circ} \mathrm{C}$ for $10 \mathrm{~min}$, and observed for spots.

Molecular weight was approximately determined by passing PH through a $8 \mathrm{~mm} \times 150-\mathrm{mm}$ column of Sephadex G200 (Sigma) at room temperature. MCDM was used as the eluant and the void volume was determined with $1.5 \%$ dextran blue 2000 . Fractions $(0.5 \mathrm{ml})$ were collected and screened for haemolytic activity.

Isolation of a non-haemolytic mutant of $E$. coli. The haemolytic strain of $E$. coli was inoculated into $10 \mathrm{ml}$ of sterile CDM containing mitomycin C $0.40 \mu \mathrm{g} / \mathrm{ml}$ (ICN Pharmaceuticals Inc., Cleveland, $\mathrm{OH}$ ), and incubated with shaking in a $37^{\circ} \mathrm{C}$ water bath. After $24-\mathrm{h}$ and 48 -h, samples were plated onto blood-agar plates. Non-haemolytic colonies were selected and characterised by biochemical tests as described above for the haemolytic strain.

Preparation of antiserum and immunoglobulins. New Zealand rabbits were given intradermal injection thrice weekly for 2 weeks with $0.25 \mathrm{ml}$ of $\mathrm{CH}$. Serum was obtained 7 days after the last injection. Serum from immunised rabbits was absorbed with whole, heat-killed $\left(100^{\circ} \mathrm{C}\right.$ for $30 \mathrm{~min}$ ), washed, non-haemolytic E. coli cells. Equal volumes of serum and packed cells were mixed, incubated for $5 \mathrm{~h}$ at $40-45 \mathrm{C}$ and overnight at $4{ }^{\circ} \mathrm{C}$, then separated by centrifugation.

Immunoglobulins were precipitated from serum by addition of an equal volume of saturated $\left(\mathrm{NH}_{4}\right)_{2} \mathrm{SO}_{4}$ and were resuspended in saline to one-fifth of the original volume. Serial twofold dilutions of immunoglobulin or serum samples to be assayed for antihaemolytic activity were made in calcium saline such that the final volume was $0.5 \mathrm{ml}$. A volume of $\mathrm{CH}$ or $\mathrm{PH}$ sufficient to cause $100 \%$ lysis of $1 \mathrm{ml}$ of $1 \%$ SRBC was brought up to $0.5 \mathrm{ml}$ and then added to each tube. The tubes were incubated at $37 \mathrm{C}$ for $15 \mathrm{~min}$. One $\mathrm{ml}$ of $1 \% \mathrm{SRBC}$ was then added to each tube and the tubes were reincubated for $1 \mathrm{~h}$. The dilution of immunoglobulin or serum that neutralised $50 \%$ of the haemolysin was taken as the titre.

Immunodiffusion. Immunodiffusion agar was prepared as described by Burrell (1979) except that $0.01 \%$ sodium azide was added. Agar was poured into $60 \times 15-\mathrm{mm}$ plastic dishes to a depth of $3 \mathrm{~mm}$ and the wells were cut $5 \mathrm{~mm}$ apart. Immunodiffusion was done at $37^{\circ} \mathrm{C}$ for 2 days after which the wells were refilled with $3.5 \%$ polyethylene glycol to precipitate the immune complexes, and reincubated at $37^{\circ} \mathrm{C}$ for 1 day.

Assay of cytotoxic activity. Mouse-fibroblast 3T3 cells were grown in Dulbecco's modified Eagle medium (DME) with 10\% fetal calf serum (Gibco, Grand Island, NY). Incubation was at $37 \mathrm{C}$ in $5 \% \mathrm{CO}_{2}$. Confluent monolayers were detached with trypsin and washed once with an equal volume of DME with $50 \%$ serum. After washing, the cell pellet was resuspended in DME and seeded either diluted or undiluted onto new plates.

For measurement of cytotoxic activity, detached 3T 3 cells were washed and resuspended in DME. Trypan blue was added to a portion of the cell suspension and viable cells counted in a haemacytometer. A known number of cells $\left(10^{5}-10^{6}\right.$ cells) was added to vials and the volume was brought up to $4.5 \mathrm{ml}$ with DME. The vials were gassed with a $\mathrm{CO}_{2}$-air mixture and incubated with shaking $(200 \mathrm{rpm})$ at $37^{\circ} \mathrm{C}$ for $2 \mathrm{~h}$. Viable-cell counts were then done on each vial, the test sample was added and the vials were reincubated. Viable counts were done at intervals up to $60 \mathrm{~min}$. 


\section{RESULTS}

\section{Purification of $\alpha$ haemolysin}

Fractionation of the crude haemolysin on a glycerol gradient resulted in a marked separation of endotoxin and other proteins from the haemolysin (fig. 1). A single protein peak was associated with haemolytic activity. The consistent appearance of a shoulder on the haemolytic-activity curve (see arrow, fig. 1) suggests the existence of two species of haemolysin.

A non-haemolytic mutant of $E$. coli, obtained by treatment of the haemolytic parent with mitomycin $\mathrm{C}$, was identical to the parent in all biochemical characteristics tested. Concentrated culture filtrates from the mutant were fractionated on glycerol gradients, and the major protein peak that coincided with peak haemolytic activity in the parent strain (fig. 1) was

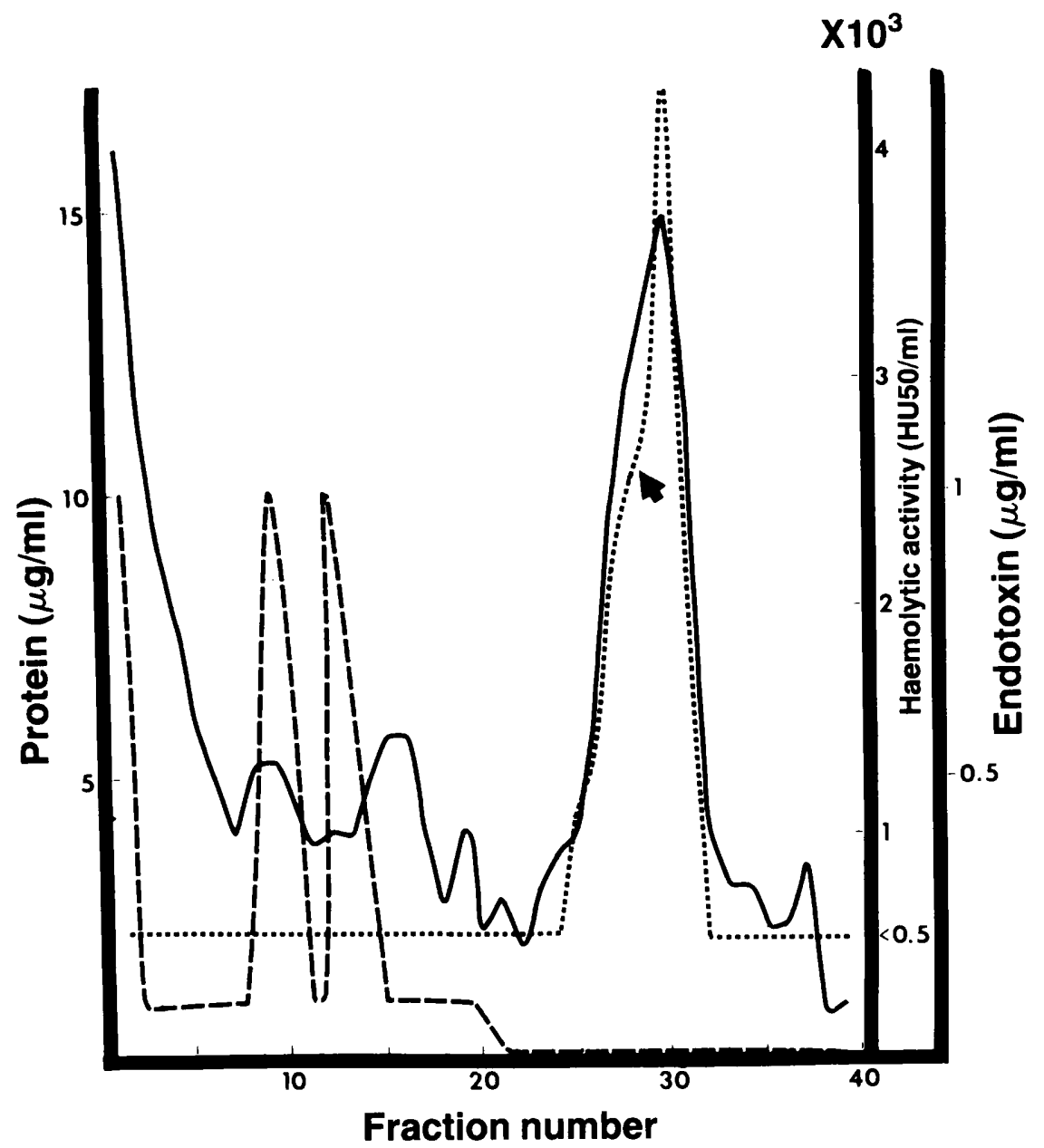

FIG. 1.-Fractionation of crude haemolysin on a 5-30\% glycerol gradient. $-=$ Protein concentration; $\ldots .=$ haemolytic activity; $---=$ endotoxin concentration. The arrow indicates a shoulder suggesting the existence of two species of haemolysin. 
absent. In all other respects the protein curves for the two strains were identical (data not shown).

Immunodiffusion analysis of haemolysin preparations revealed one precipitation line between $\mathrm{PH}$ and unabsorbed anti-haemolysin serum, and this line demonstrated identity with a single precipitation line seen between $\mathrm{PH}$ and absorbed antiserum. Immunodiffusion between unabsorbed antiserum and $\mathrm{CH}$ revealed two precipitation lines, one of which demonstrated identity with the precipitation line between $\mathrm{PH}$ and unabsorbed antiserum. The other was removed by absorption. Precipitation lines were not observed between $\mathrm{CH}$ or $\mathrm{PH}$ and preimmune serum.

Table I shows the data on the samples and fractions obtained during purification. The reason for the almost twofold increase in activity after ultrafiltration of the haemolytic culture filtrate is unclear. The use of a glycerol gradient for further purification resulted in a final product with a 19.4-fold increase in specific haemolytic activity and a recovery of $111 \%$ of the initial activity. The total endotoxin content of the purified haemolysin was lowered from $740 \mu \mathrm{g}$ in the culture filtrate to $0.34 \mu \mathrm{g}$ in the purified haemolysin, a reduction of more than 2000 -fold. The fraction that contained the highest haemolytic titre and the fraction on each side were pooled, dialysed and used in the cytotoxicity experiments.

Recovery of haemolytic activity after dialysis ranged from $75 \%$ to $100 \%$. The activity of $\mathrm{PH}$ was stable for months at $-20^{\circ} \mathrm{C}$ and for several days at $4^{\circ} \mathrm{C}$.

Chemical analysis of $\mathrm{PH}$ did not reveal detectable lipid, heptoses or KDO. However, carbohydrate $75 \mu \mathrm{g} / \mathrm{ml}$ was detected in a sample of PH containing protein $6 \cdot 2 \mu \mathrm{g} / \mathrm{ml}$. The molecular weight of $\mathrm{PH}$ exceeded 300000 because it was excluded by a 300000 molecular-weight cut-off filter and appeared in the void volume after chromatography on Sephadex G200.

\section{Cytotoxicity of purified haemolysin to mouse-fibroblast $3 T 3$ cells}

In preliminary experiments, PH was added directly to 3T3-cell monolayers.

TABLE I

Purification of E. coli $\alpha$ haemolysin

\begin{tabular}{l|cccccccc}
\hline & $\begin{array}{c}\text { Total } \\
\text { volume } \\
(\mathrm{ml})\end{array}$ & $\begin{array}{c}\text { Total } \\
\text { protein } \\
(\mathrm{mg})\end{array}$ & $\begin{array}{c}\text { Total } \\
\text { haemolytic } \\
\text { activity } \\
(\mathrm{HU})\end{array}$ & $\begin{array}{c}\text { Specific } \\
\text { haemolytic } \\
\text { activity } \\
(\mathrm{HU} / \mathrm{mg})\end{array}$ & $\begin{array}{c}\text { Relative } \\
\text { specific } \\
\text { activity }\end{array}$ & $\begin{array}{c}\text { Percentage } \\
\text { yield of } \\
\text { total } \\
\text { activity }\end{array}$ & $\begin{array}{c}\text { Total } \\
\text { endotoxin } \\
(\mu \mathrm{g})\end{array}$ & $\begin{array}{c}\text { Fold } \\
\text { decrease } \\
\text { in } \\
\text { endotoxin }\end{array}$ \\
\hline $\begin{array}{c}\text { Culture } \\
\text { filtrate }\end{array}$ & 740 & 5.92 & 69560 & 11750 & 1 & 100 & 740 & $\ldots$ \\
$\begin{array}{c}\text { Concentrated } \\
\text { culture filtrate }\end{array}$ & 24 & 1.10 & 129336 & 117578 & 10 & 186 & 24 & 31 \\
$\begin{array}{c}\text { Haemolytic } \\
\text { fractions } \\
\text { from glycerol } \\
\text { gradient* }\end{array}$ & 7 & 0.34 & 77448 & 227788 & 19.4 & 111 & 0.34 & 2176 \\
\hline
\end{tabular}

HU $50=50 \%$ haemolytic units.

* All data in this row are from one gradient and have been adjusted (except the volume) to the 24-ml total volume of concentrated culture filtrate of which $5 \mathrm{ml}$ per gradient was applied. 
Cytotoxicity in the form of cell detachment and death was observed. Because this response was difficult to measure, cell suspensions were used, and 3T3 cells were incubated for $1 \mathrm{~h}$ with different concentrations of PH. The dose-response curve was approximately linear over a range of $0-10 \mathrm{HU} 50 / \mathrm{ml}$ of $\mathrm{PH}$ (fig. 2). The curve levelled off at higher doses with $100 \%$ mortality occurring at $25 \mathrm{HU} 50 / \mathrm{ml}$ of $\mathrm{PH}$. As little as $10 \mathrm{HU} 50 / \mathrm{ml}$ of $\mathrm{PH}(23 \mathrm{ng}$ of protein killed more) than $90 \%$ of $3 \mathrm{~T} 3$ cells - as many as $4.3 \times 10^{5}$ cells $/ \mathrm{ml}$.

To determine the effect of time on the progression of cytotoxicity, $3 \mathrm{~T} 3$ cells were incubated at $37^{\circ} \mathrm{C}$ with $100 \mathrm{HU} 50 / \mathrm{ml}$ and assayed at several time intervals (fig. 3). More than $70 \%$ of $3 \mathrm{~T} 3$ cells were killed after $15 \mathrm{~min}$, and killing was approximately linear during $0-30 \mathrm{~min}$. A cytotoxic effect (15\% mortality) over control values $(5 \%$ mortality) was found after $5 \mathrm{~min}$ of incubation. Complete killing (99-100\% mortality) occurred after 45-60 min $-4.9 \times 10^{5}$ cells $/ \mathrm{ml} \mathrm{killed.} \mathrm{Control} \mathrm{values} \mathrm{(haemolysin} \mathrm{not} \mathrm{added)} \mathrm{remained} \mathrm{at} \mathrm{or} \mathrm{near} 0 \%$ mortality throughout the incubation period of $60 \mathrm{~min}$.

To obtain more evidence that cytotoxicity was due specifically to $\mathrm{PH}$, a preparation containing $20 \mathrm{HU} 50 / \mathrm{ml}$ was incubated at $37^{\circ} \mathrm{C}$ for $15 \mathrm{~min}$ with a quantity of absorbed antihaemolysin immunoglobulins sufficient to neutralise

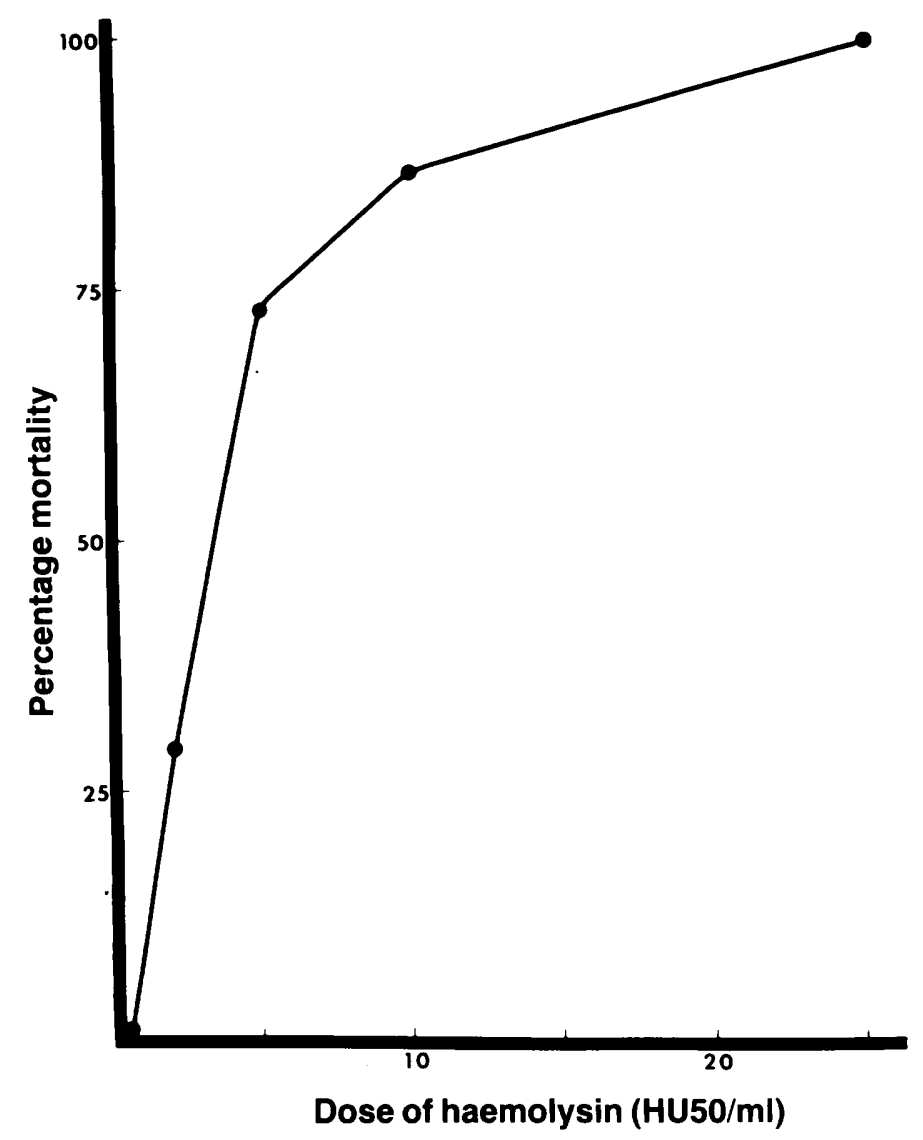

FIG. 2.-Dose-response kinetics of 3T3 cells to purified $\alpha$ haemolysin. 


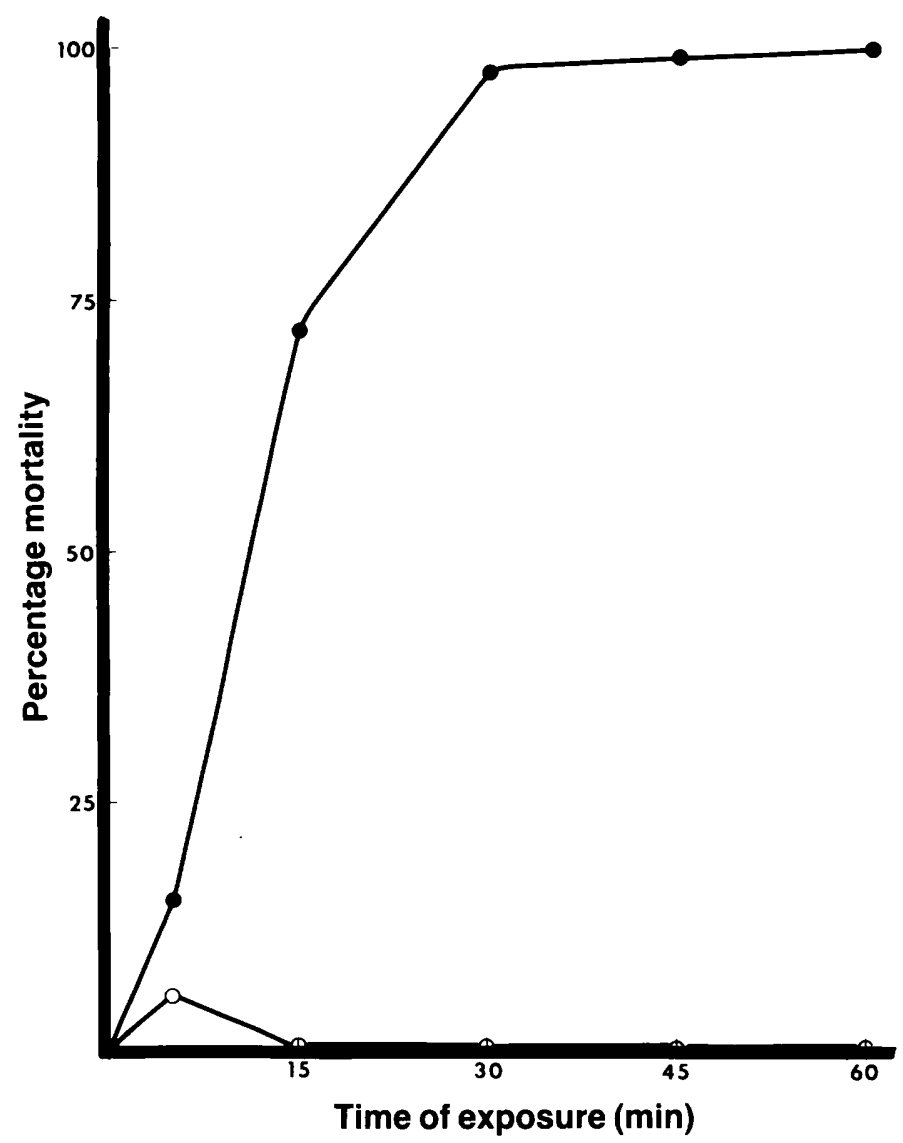

FIG. 3.-Time-course kinetics of 3T3 cells exposed to $100 \mathrm{HU} 50$ of purified haemolysin/ml of cell suspension $(\bullet)$ or an equal volume of MCDM (O). See Materials and methods for composition of MCDM.

haemolytic activity. The same concentration of $\mathrm{PH}$ was also incubated with the same amount of immunoglobulin from preimmune serum. After incubation, the samples were brought up to $1 \mathrm{ml}$ with MCDM and added to $3 \mathrm{ml}$ of 3T3-cell suspension $\left(7 \cdot 4 \times 10^{5} \mathrm{cells} / \mathrm{ml}\right)$. PH treated with antihaemolysin immunoglobulin was not cytotoxic whereas PH treated with the same concentration of immunoglobulin from preimmune serum retained its cytotoxicity. Heat treatment also reduced the cytotoxic (table II) and haemolytic activities of $\mathrm{PH}$ threefold and tenfold respectively.

In addition, concentrated culture filtrates from the haemolytic parent were haemolytic for SR BC and cytotoxic for 3T3 cells whereas concentrated culture filtrates from the non-haemolytic mutant were neither haemolytic nor cytotoxic (data not shown).

To rule out the possibility that endotoxin caused the cytotoxicity, 3T3 cells were incubated with six times the amount of endotoxin found in 20 HU50 of PH $\left(2 \cdot 5 \times 10^{-4} \mu \mathrm{g} / \mathrm{ml}\right)$. No effect on $3 \mathrm{~T} 3$ cells was obtained. 
TABLE II

Neutralisation of the cytotoxic effect of purified $\alpha$ haemolysin on mouse-fibroblast $3 T 3$ cells by antibody and heat

\begin{tabular}{|c|c|}
\hline Treatment & $\begin{array}{l}\text { Percentage } \\
\text { mortality }\end{array}$ \\
\hline $\begin{array}{l}\mathrm{PH} 20, \mathrm{HU} 50 / \mathrm{ml} \\
\mathrm{PH} 20, \mathrm{HU} 50 / \mathrm{ml}+\end{array}$ & $\begin{array}{l}88 \cdot 3 \\
14 \cdot 5\end{array}$ \\
\hline $\begin{array}{c}\mathrm{PH}, 20 \mathrm{HU} 50 / \mathrm{ml}+ \\
\text { preimmune } \mathrm{Ig}\end{array}$ & $81 \cdot 4$ \\
\hline $\begin{array}{l}\text { Anti-haemolysin Ig } \\
\text { Heated* PH, } 20 \mathrm{HU} 50 / \mathrm{ml} \\
\text { Buffer }\end{array}$ & $\begin{array}{r}7 \cdot 1 \\
30 \cdot 9 \\
17 \cdot 6\end{array}$ \\
\hline
\end{tabular}

$\mathrm{PH}=$ purified $\alpha$ haemolysin; $\mathrm{Ig}=$ immunoglobulin preparation (see Methods).

$* 100^{\circ} \mathrm{C}$ for $15 \mathrm{~min}$.

\section{Discussion}

The aims of this study were to purify $E$. coli $\alpha$ haemolysin and determine its cytotoxicity. These objectives are important for further definition of the role of $\alpha$ haemolysin in the virulence of $E$. coli.

A 19-fold increase in specific activity of the haemolysin was obtained by glycerol-gradient ultracentrifugation of concentrated culture filtrates of haemolytic E. coli. This is of the same order as the 23-fold purification reported by Zwadyk and Snyder (1971), but is much lower than the values reported by others (Rennie and Arbuthnott, 1974; Williams, 1979). This may be due to the fact that these workers grew the organisms in meat-infusion or nutrient-broth medium which, because of large amounts of protein present, results in a low initial specific activity and the appearance of greater purification. However the relative final specific activity of our $\mathrm{PH}$, approximately $228000 \mathrm{HU} 50 / \mathrm{mg}$, is comparable with the $10^{6} \mathrm{HU} / \mathrm{mg}$ reported by Rennie and Arbuthnott (1974) and $109000 \mathrm{HU} / \mathrm{mg}$ reported by Williams (1979).

Other workers (Short and Kurtz, 1971; Zwadyk and Snyder, 1971; Rennie and Arbuthnott, 1974; Williams, 1979) did not include a determination of endotoxin concentration or purity by immunological assays. In our study, purification of $\alpha$ haemolysin resulted in a 2176-fold reduction of the endotoxin content, and immunodiffusion analysis suggests the presence of only one antigen. Attempts to electrophorese $\alpha$ haemolysin preparations on conventional polyacrylamide gels were unsuccessful, even though the gel concentrations were varied to allow for entry of the molecule.

Fractionation of $\mathrm{CH}$ on glycerol gradients occasionally yielded a haemolytic curve with one or more shoulders, suggesting the presence of more than one species of haemolysin. This is in agreement with the findings of Short and Kurtz (1971) who reported the recovery of two peaks with haemolytic activity after fractionation of haemolytic filtrates on Sephadex G200, and Rennie and Arbuthnott (1974) who found that fractionation of $\alpha$ haemolysin on Sephadex G200, in conditions that reduced aggregation, resulted in two peaks of haemolytic activity. The protein profile of concentrated culture filtrates of our 
non-haemolytic mutant did not contain a protein peak in the area where haemolytic activity was found in protein profiles of fractionated $\mathrm{CH}$, suggesting that this protein peak is haemolysin.

Lipids were not detected in samples of PH. However, a significant amount of carbohydrate was detectable. This is in contrast to the findings of Rennie and Arbuthnott (1974) and Zwadyk and Snyder (1971) who did not find carbohydrates in haemolysin produced by $E$. coli grown in meat-infusion media. The possibility exists that the presence of this carbohydrate is due to endotoxin contamination. However, the small amount of endotoxin in $\mathrm{PH}$ as detected by the limulus test and the absence of heptoses and KDO, argue against this hypothesis. Whether this carbohydrate represents contamination or is actually part of the haemolysin molecule is unknown and will require more research. Unpublished data from our laboratory show that haemolytic activity of $\mathrm{PH}$ is destroyed by proteases, suggesting that protein is required for activity.

The high molecular weight of PH estimated by its exclusion from Sephadex G200 and its retention by a 300000 molecular-weight filter is in agreement with the findings of Rennie and Arbuthnott (1974).

Little work has been done on the toxicity of purified $E$. coli $\alpha$ haemolysin for cells other than erythrocytes. Our study revealed that 3T3 cells in monolayers exposed to $\mathrm{PH}$ were killed and became detached, but this response was difficult to measure. In preliminary experiments with trypsinised washed-cell suspensions, our results were not reproducible and a proportional dose-response relationship could not be established. However, incubation of trypsinised and washed-cell suspensions in cell-culture medium for $2 \mathrm{~h}$ before the addition of $\mathrm{PH}$ resulted in a consistent dose-response curve, suggesting that the receptor sites on the cell membrane are destroyed or modifed during the trypsinisation. Others have noted that trypsinised human embryonic intestinal cells are insensitive to staphylococcal enterotoxin B, but that the cells became sensitive again after further incubation (Schaeffer, Gabliks and Calitis, 1967).

The dose-response curve for 3T3 cells treated with PH was linear over a range of $0-10$ HU50. Similar data were reported for the cytotoxic effects of other haemolysins (Snyder and Hamilton, 1963; Wiseman, 1968; Thelestam, Möllby and Wadström, 1973; Möllby, Thelestam and Wadström, 1974). In addition, the dose-response kinetics for 3T3-cell cytotoxicity were similar to those reported for erythrocyte lysis by Rennie, Freer, and Arbuthnott (1974). As little as 10 HU50 (23 ng of protein) of PH killed $90 \%$ or $4.3 \times 10^{5} 3 \mathrm{~T} 3$ cells and even 2 HU50 showed significant killing. By comparison, $10 \mathrm{HU}$ of streptolysin $\mathrm{S}$ is the minimum amount that kills $10^{5} \mathrm{McCoy}$ cells, with as little as $0.5 \mathrm{HU}$ reducing the viable cell counts to $25 \%$ of control values (Snyder and Hamilton, 1963).

The time kinetics for erythrocyte lysis (Rennie et al., 1974) and for 3T3-cell killing by $E$. coli $\alpha$ haemolysin are linear and depend on haemolysin concentration. The kinetics of 3T3-cell cytotoxicity were consistent with the single-hit hypothesis for $\alpha$ haemolysin proposed by Short and Kurtz (1971) and Jorgensen, Hammer and Wu (1980).

Neutralisation of the cytotoxic and haemolytic activity of $\mathrm{PH}$ was achieved 
by heat and by immunoglobulins from immune sera. In addition, cells treated with endotoxin did not show a loss of viability. Singer and Dutton (1979) have shown that it takes endotoxin at a concentration of at least $100 \mu \mathrm{g} / \mathrm{ml}, 10^{6}$-fold more than is present in $\mathrm{PH}$ samples, to cause cytotoxicity for mouse fibroblasts. Furthermore, filtrates from a non-haemolytic mutant were neither haemolytic nor cytotoxic. All these data suggest that the haemolytic and cytotoxic activities are caused by the same molecule.

We have shown that purified $E$. coli $\alpha$ haemolysin is cytotoxic and further work will be devoted to elucidating its mechanism of action and to defining its role in disease.

This work was supported in part by Biomedical Research Support Grant 5 SO7 RR 05433-18 and by the West Virginia University Medical Corporation. S. J. C. was supported by a Swiger Foundation Fellowship.

\section{REFERENCES}

BRADFORD, M. M. 1976. A rapid and sensitive method for the quantitation of microgram quantities of protein utilizing the principle of protein-dye binding. Anal. Biochem., 72, 248.

Burrell, R. 1979. Experimental immunology, 5th ed., Burgess Publishing Co., Minneapolis, Minn, p. 41.

Chaturvedi, U. C., Mather, A., Khan, A. M. and Mehrotra, R. M. L. 1969. Cytotoxicity of filtrates of haemolytic Escherichia coli. J. med. Microbiol., 2, 211.

DePauw, A. P., GiLl, W. B. AND Fried, F. A. 1971. Etiology of pyelonephritis: renal lysosome disruption by hemolytic Escherichia coli. Invest. Urol., 9, 230.

Dubois, M., Gilles, K. A., Hamilton, J. K., Rebers, P. A. And Smith, F. 1956. Colorimetric method for determination of sugars and related substances. Anal. Chem., 28, 350.

Edwards, P. R. AND EwING, W. H. 1972. In Identification of Enterobacteriaceae, 3rd ed., Burgess Publishing Co., Minneapolis, Minn, p. 21.

FrIED, F. A. AND WONG, R. J. 1970. Etiology of pyelonephritis: significance of hemolytic Escherichia coli. J. Urol., 103, 718.

Fry, T. L., FrIED, F. A. AND Goven, B. A. 1975. Pathogenesis of pyelonephritis: Escherichia coli-induced renal ultrastructural changes. Invest. Urol., 13, 47.

JoRgensen, S. E., Hammer, R. F. AND WU, G. K. 1980. Effects of a single hit from the alpha hemolysin produced by Escherichia coli on the morphology of sheep erythrocytes. Infect. Immun., 27, 988.

KATES, M. 1972. Techniques of lipidology. Isolation, analysis, and identification of lipids. Laboratory techniques in biochemistry and molecular biology, vol. 3, North-Holland Publishing Co., Amsterdam, pp. 347-353, 393-469.

Minshew, B. H., Jorgensen, J., Counts, G. W. and Falkow, S. 1978a. Association of hemolysin production, hemagglutination of human erythrocytes and virulence for chicken embryos of extra-intestinal Escherichia coli isolates. Infect. Immun., 20, 50.

Minshew, B. H., Jorgensen, J., Swanstrum, M., Grootes-Reuvecamp, G. A. and Falkow, S. 1978b. Some characteristics of Escherichia coli strains isolated from extraintestinal infections of humans. J. infect. Dis., 137, 648.

Möllby, R., Thelestam, M. AND WAdSTRÖM, T. 1974. Effects of Clostridium perfringens phospholipase $\mathrm{C}$ (alpha-toxin) on the human diploid fibroblast membrane. J. membr. Biol., 16, 313.

OSBORN, M. J. 1963. Studies on the gram-negative cell wall, I. Evidence for the role of 2-keto-3-deoxyoctonate in the lipopolysaccharide of Salmonella typhimurium. Proc. natn. Acad. Sci. U.S.A., 50, 499.

Rennie, R. P. AND ARbuthnott, J. P. 1974. Partial characterisation of Escherichia coli haemolysin. J. med. Microbiol., 7, 179. 
Rennie, R. P., Freer, J. H. And Arbuthnott, J. P. 1974. The kinetics of erythrocyte lysis by Escherichia coli haemolysin. J. med. Microbiol., 7, 189.

SCHAEFFER, W. I., GABLIKS, J. AND CALITIS, R. 1967. Interference by trypsin in the interaction of staphylococcal enterotoxin B and cell cultures of human embryonic intestine. J. Bact., 93, 1489.

Short, E. C. And Kurtz, H. J. 1971. Properties of the hemolytic activities of Escherichia coli. Infect. Immun., 3, 678.

Singer, R. E. AND DutTon, W. G. 1979. A comparison of the effects of endotoxin upon fibroblast proliferation and macromolecular synthesis. J. dent. Res., 58, 1634.

Smith, H. W. 1963. The haemolysins of Escherichia coli. J. Path. Bact., 85, 197.

SмITH, H. W. AND LINGGOOD, M. A. 1971. Observations on the pathogenic properties of the $\mathrm{K} 88$, hly, and ent plasmids of Escherichia coli with particular reference to porcine diarrhoea. J. med. Microbiol., 4, 467.

SNyder, I. S. And Hamilton, T. R. 1963. Effect of streptolysin S on mammalian cells. J. Path. Bact., 86, 242.

SNYDER, I. S. AND Косн, N. A. 1966. Production and characteristics of hemolysins of Escherichia coli. J. Bact., 91, 763.

Thelestam, M., Möllby, R. AND WADSTRÖm, T. 1973. Effects of staphylococcal alpha-, beta-, delta-, and gamma-hemolysins on human diploid fibroblasts and HeLa cells: evaluation of a new quantitative assay for measuring cell damage. Infect. Immun., 8, 938.

WaravdeKar, V. S. AND SASLAW, L. D. 1959. A sensitive colorimetric method for the estimation of 2-deoxy sugars with the use of the malonaldehyde-thiobarbituric acid reaction. J. biol. Chem., 234, 1945.

Ward, P. A. AND Hill, J. H. 1972. Detection of lipopolysaccharide (LPS): an improved method for isolation of the Limulus extract. Proc. Soc. exp. Biol. Med., 141, 898.

Williams, P. H. 1979. Determination of the molecular weight of Escherichia coli $\alpha$-hemolysin. F.E.M.S. Microbiol. Letts., 5, 21.

WISEMAN, G. M. 1968. The nature of staphylococcal beta hemolysin. II. Effect on mammalian cells. Can. J. Microbiol., 14, 179.

ZWADYK, P. AND SNYDER, I. S. 1971. Purification and kinetic studies of the hemolysin from Escherichia coli. Can. J. Microbiol., 17, 741. 